\author{
Joanna Stanisz \\ Katedra Socjologii Sztuki \\ Instytut Socjologii \\ Wydział Ekonomiczno-Socjologiczny \\ Uniwersytet Łódzki
}

\title{
Współczesne oblicze lódzkich teatrów w opiniach twórców teatralnych
}

\section{Wstęp}

Łódź jest jednym z największych miast w Polsce. W 2009 r., według danych Głównego Urzędu Statystycznego, miasto liczyło 742, 4 tys. mieszkańców ${ }^{1}$, co plasuje je na trzecim miejscu w kraju. Jest dużym ośrodkiem akademickim (sześć uczelni państwowych) oraz kulturalnym (kina, teatry, muzea, galerie sztuki, domy kultury). Łódź była niegdyś postrzegana jako filmowe centrum Polski. Oprócz znanej na całym świecie szkoły filmowej, dysponowała licznymi studiami nagrań. To tutaj przyjeżdżali aktorzy z całej Polski na castingi, to tutaj kręcone były filmy. Łódzkie ulice służyły jako plener do ponad 150 filmów/seriali (np. Ziemia obiecana, Zakazane piosenki, Daleko od szosy, Aleja gówniarzy).

Tuż po wojnie Łódź, na krótki czas, stała się kulturalną stolicą Polski. Dobre chwile nie trwały jednak długo. Odradzająca się stolica przejęła czołowych artystów, dziennikarzy, ludzi kultury. Miasto straciło pozycję lidera, a dla wielu de facto stało się kulturalną prowincją. Pogląd ten pokutuje do dziś - niezależnie od tego, ile w Łodzi się dzieje oraz jakie są realne możliwości miasta.

Niniejszy artykuł poświęcony jest teatralnemu życiu Łodzi. Jest on efektem wywiadów z czołowymi postaciami łódzkich teatrów - ludźmi, którym zależy na jakości teatralnego życia Łodzi, którzy reprezentują nasze miasto na arenie krajowej. Do rozmów zaprosiłam Bronisława Wrocławskiego, Zdzisława Jaskułę, Ewę Pilawską, Marcina Brzozowskiego i Agnieszkę Więdłochę.

Bronisław Wrocławski - absolwent Wydziału Aktorskiego PWSFTviT, dziekan Wydziału Aktorskiego PWSFTviT w Łodzi, aktor teatralny, telewizyjny i filmowy, laureat wielu prestiżowych nagród (Honorowa Odznaka Miasta Łodzi, Srebrny Pierścień - nagroda Wydziału Kultury i Sztuki Urzędu Miejskiego

\footnotetext{
${ }^{1} \mathrm{http} / / /$ www.stat.gov.pl/cps/rde/xbcr/gus/PUBL_oz_maly_rocznik_statystyczny_2011.pdf, s. 644, [09.05.2012].

${ }^{2}$ http://filmpolski.pl/fp/index.php/118010, [09.05.2012].
} 
w Łodzi, Złoty Krzyż Zasługi z okazji obchodów 110-lecia Teatru Jaracza w Łodzi, Odznaczenie (Brązowy Medal Gloria Artis), wiele nagród aktorskich); od lat związany jest z Teatrem im. Stefana Jaracza.

Zdzisław Jaskuła ${ }^{3}$ - dyrektor Teatru Nowego, pisarz, poeta, od wielu lat związany z światem łódzkich teatrów, bohater filmu biograficznego Zdzisław Jaskuła - poeta z ulicy Wschodniej ${ }^{4}$, laureat wielu nagród za działalność teatralną, odznaczony Krzyżem Oficerskim OOP oraz Srebrnym Medalem Gloria Artis - Zasłużony Kulturze.

Ewa Pilawska ${ }^{5}$ teatrolog, dyrektorka Teatru Powszechnego, Lodzianka Roku 2000, laureatka wielu nagród, w tym: Nadzwyczajnej Złotej Maski (2001) za zbudowanie zespołu Teatru Powszechnego, konsekwentne budowanie repertuaru oraz organizację Festiwalu Sztuk Przyjemnych.

Marcin Brzozowski ${ }^{6}$ - absolwent Wydziału Aktorskiego PWSFTviT w Łodzi, założyciel Teatru Szwalnia, aktor teatralny, telewizyjny i filmowy, pedagog. Jego monodram Clapham Junction został nagrodzony na kilku krajowych festiwalach.

Agnieszka Więdłocha ${ }^{7}$ - absolwentka Wydziału Aktorskiego PWSFTviT w Łodzi; aktorka teatralna (Teatr im. Stefana Jaracza w Lodzi), telewizyjna i filmowa, laureatka nagród aktorskich, w tym Złotej Maski za najlepszy debiut sceniczny sezonu 2009/2010.

Dzięki wywiadom swobodnym przeprowadzonym z wymienionymi wyżej artystami (w ciągu kilku miesięcy - od grudnia 2011 do kwietnia 2012 r.) powstał obraz Łodzi teatralnej - nie zawsze malowany pastelowymi barwami. Zacznę jednak od rysu historycznego, następnie przejdę do omówienia poszczególnych tematów poruszanych w trakcie wywiadów, by zakończyć opisem zwracającym się ku przyszłości (obraz Łodzi, jaki chcieliby urzeczywistnić indagowani).

\section{2. Łódź teatralna - rys historyczny}

Początki łódzkiego teatru sięgają roku 1844. W Łodzi nie istniał wtedy jeszcze żaden instytucjonalny teatr, jednakże miasto odwiedzały wędrowne trupy aktorskie. Dostarczały one łodzianom rozrywki, stanowiły ucieczkę od ponurej i trudnej codzienności. Ciągle jednak brakowało warunków do prawdziwej celebracji sztuki. W Łodzi nie było odpowiednio przygotowanych sal teatralnych - a tym samym godnych warunków do pracy dla artystów i minimalnej choćby wygody odbioru dla widzów.

\footnotetext{
${ }^{3} \mathrm{http}: / /$ www.e-teatr.pl/pl/osoby/6510,karierazawod.html\#start, [09.05.2012].

${ }^{4}$ http://filmpolski.pl/fp/index.php/4215348, [09.05.2012].

${ }^{5} \mathrm{http}: / /$ www.e-teatr.p1/pl/osoby/15551,nagrody.html\#start, [09.05.2012].

${ }^{6} \mathrm{http}: / /$ www.filmpolski.pl/fp/index.php/1133987, [09.05.2012].

${ }^{7}$ http://www.e-teatr.pl/pl/osoby/60677,nagrody.html\#start, [09.05.2012].
} 
Najbardziej znaną była grupa Marzantowicza, którą do Łodzi z Łęczycy sprowadził jeden z radnych. „Aktorzy zamieszkali w zajeździe na rogu placu Kościelnego i ulicy Zgierskiej i dali kilka przedstawień w szopie, będącej być może, wozownią zajazdu"•. Pierwszym widowiskiem teatralnym, jakie mieli okazję zobaczyć łodzianie, była inscenizacja melodramatu francuskiego Joanna, czyli kobieta z gminu ${ }^{9}$.

Pierwsze próby powołania stałej sceny miały miejsce $\mathrm{w} 1888 \mathrm{r} \cdot{ }^{10}$ Wtedy to Łucjan Kościelecki zorganizował teatr w hotelu Victoria ${ }^{11}$. Oznaczało to poprawę warunków pracy aktorów. Niestety samo przedsięwzięcie nie było sukcesem. Kolejne zmiany dyrekcji (1890 - Karol Kopczewski, 1892 - Czesław Janowski) nie przyniosły poprawy ${ }^{12}$. W 1895 r. do Łodzi zawitał Michał Wołowski. Oprócz modernizacji Victorii zasłynął on powołaniem pierwszego na ziemiach polskich teatru dla robotników. „Charakterystyczny jest finał tej dyrekcji: zrezygnowawszy z repertuaru operetkowego, Wołowski okupił swoje ambicje artystyczne bankructwem i przedwczesną śmiercią (18 V 1900)"13.

Na stabilizację życia teatralnego Łódź musiała poczekać do $1901 \mathrm{r}$. Wtedy to przy ulicy Legionów 14 wzniesiono pierwszy gmach Teatru Wielkiego. $\mathrm{Z}$ czasem, miasto ubogie w instytucje kultury zyskało kolejne budynki teatralne. W 1918 r. Łódź mogła zaprosić widzów do pięciu teatrów. Niezależnie od nich funkcjonowało kilkadziesiąt sal przystosowanych do występów kabaretowych, rewiowych - zarówno profesjonalnych, jak i amatorskich ${ }^{14}$. W tym czasie (1901-1918) z Łodzią swe życie zawodowe związało wielu wspaniałych artystów: Aleksander Zelwerowicz (od 1908 do 1911 r. był on dyrektorem Teatru Polskiego) ${ }^{15}$, wraz z nim do miasta zawitali znakomici aktorzy, m. in. Stefan Jaracz, Władysław Grabowski, Jadwiga Czechowska, Jadwiga Żmijewska, Kazimierz Junosza-Stępowski ${ }^{16}$. Najwytrwalszym budowniczym Łodzi teatralnej był Fryderyk Sellin. Z jego inicjatywy powstały trzy budynki służące sztuce teatru: Arkadia, Teatr Letni oraz Teatr Wielki ${ }^{17}$.

Najlepsze chwile dla łódzkiego teatru przypadają na okres powojenny, kiedy to wiele instytucji, opuszczając zburzoną Warszawę, odnalazło schronienie

${ }^{8}$ J. Urbankiewicz, Sezon w Łodzi nie zaszkodzi, Łódź 1978, s. 6.

${ }^{9}$ Ibidem.

${ }^{10}$ Równocześnie z innego artykułu wynika, że stała scena teatru w Łodzi powstała w 1853 r., w ogrodzie Paradyż przy ulicy Piotrkowskiej 175a (por. A. Kuligowska, Eódzka publiczność teatralna w XIX wieku, [w:] Sto lat stałej sceny polskiej w Łodzi 1888-1988, red. A. Kuligowska, Łódź 1993, s. 180).

${ }^{11}$ Hotel mieścił się przy ul. Piotrkowskiej 67.

12 J. Urbankiewicz, op. cit., s. 298.

${ }^{13}$ www.uml.lodz.pl/get.php?id=268, s. 9, [9.05.2012].

${ }^{14}$ A. Kuligowska-Korzeniewska, Scena obiecana. Teatr polski w Lodzi 1844-1918, Łódź 1995, s. 247.

${ }^{15}$ Ibidem, s. $150-179$.

${ }^{16}$ Ibidem, s. 155.

${ }^{17}$ S. Kaszyński, Teatr łódzki w latach 1945-1962, Łódź 1979, s. 19. 
właśnie w Łodzi. Czasy znakomite dla kultury artystycznej nie trwały długo ${ }^{18}$. Łódzkie teatry podjęły żmudną walkę o widza, a ta stała się trudniejszą w latach pięćdziesiątych, kiedy nastąpił gwałtowny rozwój kultury masowej. Teatr zyskał rywala w postaci telewizji. W późniejszym okresie do rywalizacji o publiczność dołączył Internet. W Polsce za początek ery Internetu można przyjąć rok 1987, kiedy to uruchomiono łączność elektroniczną między Warszawą a Genewą ${ }^{19}$.

Zabieganie o widzów trwa do dziś i zapewne trwać będzie dalej. Daleka jednak jestem od obaw o publiczność teatralną. Zawsze znajdzie się grupa ludzi, którzy poszukując bezpośredniego spotkania ze sztuką, zawitają w teatralnych murach.

\section{Lódź - miasto kształcące przyszłe kadry teatrów}

W Łodzi działa jedna z najsłynniejszych w kraju uczelni artystycznych: Państwowa Wyższa Szkoła Filmowa, Telewizyjna i Teatralna im. Leona Schillera. Uczelnia ta powstała w 1948 r. - pod nazwą Wyższa Szkoła Filmowa. Warto nadmienić, że w początkach istnienia szkoły podstawowym jej założeniem była odbudowa zniszczonego przez wojnę przemysłu filmowego, przygotowanie nowych kadr filmowców, stworzenie w Łodzi centrum filmowego ${ }^{20}$. Teatr - jako ważny filar - zaistniał w jej strukturze wraz z mariażem z inną uczelnią: Państwową Wyższą Szkołą Teatralnąa ${ }^{21}$. Fuzja ta miała miejsce w 1958 r. ${ }^{22}$

Od początku swojego istnienia szkoła zajmuje kompleks budynków mieszczących się przy ulicy Targowej. Większość sal zajmują wydziały związane ze sztuką filmową. Przyszli aktorzy muszą zadowolić się kilkoma pomieszczeniami w budynku A oraz salami przystosowanymi do zajęć ze studentami przy Teatrze Studyjnym. Przyszli artyści scen polskich kształcą się pod kierunkiem znanych aktorów i reżyserów (w szkole uczą m. in. Bronisław Wrocławski, Janusz Gajos, Wojciech Malajkat, Ewa Mirowska, Jacek Orłowski i wielu innych cenionych artystów). Zwieńczeniem studiów są przygotowane przez studentów, pod opieką zaproszonych reżyserów, przedstawienia dyplomowe. Młodzi artyści mają okazję zaistnieć na prawdziwej scenie, stanąć przed publicznością i zmierzyć się z jej energią. Niezwykle ważnym wydarzeniem w życiu przyszłych aktorów jest Festiwal Szkół Teatralnych, od początku swego istnienia odbywający się w Łodzi.

${ }^{18}$ Ibidem, s. 36

${ }^{19}$ Powstanie i rozwój Internetu - kalendarium: http://www.umk.pl/ zenkiewicz/kalendarium/ polska/, [09.05.2012)].

${ }^{20}$ Państwowa Wyższa Szkoła Filmowa w Łodzi, Warszawa 1955, s. 5-6.

${ }^{21}$ Pierwotnie Wyższa Szkoła Aktorska.

${ }^{22}$ Państwowa Wyższa Szkoła Filmowa, Telewizyjna i Teatralna im. Leona Schillera w Łodzi 1948-1998. Księga jubileuszowa, red. J. Lemann, Łódź 1998. 
Jest to dla nich doskonały sprawdzian umiejętności, a także szansa na pokazanie się z jak najlepszej strony przed jury oraz zasiadającymi na widowni (niestety coraz rzadziej) dyrektorami teatrów. Festiwal ma ogromne znaczenie dla promocji Łodzi, a narodził się z inicjatywy Jana Machulskiego. Powinniśmy mu być wdzięczni nie tylko za role, które stworzył, ale i za ogromną wyobraźnię oraz wiarę w teatr i młodość... Wbrew temu, co pisała Stanisława Wysocka ${ }^{23}$, nie trzeba z żalem i tęsknotą spoglądać w przeszłość, równocześnie obawiając się tego, co obecnie dzieje się w teatrze i tego, co dopiero się stanie. Wybitne osobowości sprzed lat już nie wrócą - nie znaczy to jednak, że polski teatr chyli się ku upadkowi.

\section{Specyfika współczesnego teatru lódzkiego}

W chwili obecnej w Łodzi działają trzy teatry dramatyczne: Teatr Powszechny, Teatr im. Stefana Jaracza, Teatr Nowy; dwa teatry lalkowe: Teatr Pinokio i Teatr Arlekin oraz dwa teatry muzyczne: Teatr Wielki, Teatr Muzyczny. Teatralną mapę wzbogacają inicjatywy prywatne oraz sceny alternatywne: Teatr Szwalnia, Teatr V6, Teatr Mały. Warty wspomnienia jest również Teatr Studyjny należący do PWSFTviT. W porównaniu z ofertą teatralną Warszawy nie jest to wiele. Takie jest też zdanie moich respondentów.

Bronisław Wrocławski zauważa:

Kiedy zaczynałem swoją karierę zawodową, mając 23 lata, miałem takie marzenie [...] wtedy w Łodzi były 3 teatry dramatyczne: Powszechny, Nowy i Jaracza. Marzyłem, że za kilka lat to się zmieni, że Łódź będzie miała 14 teatrów, ponad milion mieszkańców, a ja będę zawodowo związany z kilkoma scenami. Minęło 38 lat [...] ciągle jest Teatr Powszechny, Nowy, Jaracza. Każdy z nich w swoistej dla siebie, ale czy luksusowej kondycji?

Również Agnieszka Więdłocha zauważa, że mimo ciekawej oferty, jaką przedstawiają widzom łódzkie teatry, pod względem ilościowym ustępują stolicy:

Łódź od lat toczy swoistą rywalizację (choć to może nie do końca właściwe określenie) z Warszawą, ze względu na geograficzną bliskość obu miast. Łódź niestety pozostaje w cieniu Warszawy.

Ewa Pilawska podkreśla, jak ważna jest kultura w rozwoju miast:

Uważam, że Łódź powinna być miastem kultury, to dziedzina, która przyniosłaby temu miastu renomę i mogłaby być wizytówką Łodzi. Kiedyś mieliśmy tu przemysł, ale na jego odbudowę nie ma co liczyć. Ale przecież Łódź to także kolebka, znanej w świecie, polskiej szkoły filmowej,

${ }^{23}$ S. Wysocka, Aktor i przyszłość teatru, [w:] Polska myśl teatralna i filmowa, red. T. Sivert, R. Taborski, Warszawa 1971, s. 568-575. 
miasto wybitnych artystów, poetów i twórców teatralnych. I to chyba właśnie jest przestrzeń, na której należy się skupić.

Zdzisław Jaskuła podkreśla, że łódzka oferta teatralna jest ciekawa. Równocześnie jednak zauważa, że brakuje mu pewnego fermentu, głośnych premier, które przyciągnęłyby uwagę całego kraju:

Krótko mówiąc, z Łodzi w ostatnim czasie nie wypłynęła żadna idea teatralna, brakuje wielkich wydarzeń artystycznych. Owszem, mamy ciekawe, czy bardzo dobre premiery, ale nie są one szczególnie nowatorskie czy odkrywcze.

Marcin Brzozowski zwraca uwagę na nurt pozainstytucjonalny, alternatywny oraz siłę odbywających się w mieście festiwali:

Łódź zawsze była kojarzona $\mathrm{z}$ teatrem alternatywnym i pozainstytucjonalnym. Trzeba tu przede wszystkim przywołać osobę Mariana Glinkowskiego - wieloletniego szefa Łódzkich Spotkań Teatralnych, wydarzenia o dużym znaczeniu dla polskiego teatru. Od wielu lat ten i inne łódzkie festiwale były znakiem rozpoznawczym Łodzi. Mimo iż wiele z nich z niewiadomych przyczyn upada lub opuszcza Łódź, nasze miasto wciąż kojarzone jest z kilkoma nieobecnymi już dużymi festiwalami, takimi jak Camerimage, Festiwal Dialogu Czterech Kultur.

Na podstawie zebranych wywiadów trudno jest zdefiniować specyfikę łódzkiego teatru. Marcin Brzozowski podkreśla, że teatralną Łódź w znacznej mierze tworzą osoby, które tu przyjechały - brakuje natomiast przedsięwzięć „czysto” łódzkich:

W Łodzi nie ma czegoś tak wyrazistego jak „Ósemki” w Poznaniu czy „Porywacze ciał”. Owszem działa u nas Tomasz Rodowicz. Jego „Chorea” jest wyjątkowa, jedyna w swoim rodzaju, ale to za mało. Wydaje mi się, że wciąż nie ma silnego związku między specyfiką miasta a rodzajem i tematami działań podejmowanych przez teatry. Tu również marzy mi się poszerzenie roli Szwalni. W sposób realny i widoczny zaistnieć w tkance miejskiej. Dotrzeć do ludzi, którzy $\mathrm{z}$ różnych powodów nie kontaktują się z teatrem. Wziąć na warsztat tematy dotyczące miasta, jego historii.

\section{Podobnie wypowiada się Ewa Pilawska:}

Nie wiem, czy łódzki teatr jest w jakiś konkretny sposób specyficzny. I co to tak naprawdę miałoby oznaczać? Jak mówię z dawnej, robotniczej historii tego miasta niewiele pozostało, więc trudno mówić o tego typu powiązaniach. Z drugiej strony Łódź ma wiele teatrów, z których każdy jest w jakiś sposób autorski, określony profilowo. Myślę, że o specyfice teatru w danym mieście można mówić, kiedy w danym miejscu jest jeden ośrodek teatralny, który musi odpowiedzieć na zapotrzebowanie wszystkich grup społecznych.

Aktorzy Teatru im. Stefana Jaracza natomiast uważają, że Łódź ma swój unikatowy klimat, który bywa wykorzystywany w teatralnych poszukiwaniach:

Bronisław Wrocławski, odpowiadając na moje pytanie, deklaruje: 
Od lat współpracuję z Jackiem Orłowskim. Tworząc dane przedstawienie, zawsze zadajemy sobie pytanie: a dla kogo to będzie? A ono będzie dla łódzkiego inżyniera, nauczyciela, dla łódzkiej młodzieży.

Agnieszka Więdłocha potwierdza słowa Wrocławskiego:

Klimat Łodzi bardzo wpływa na sztuki teatralne, jakie są tu oferowane widzom. Z mojego doświadczenia pracy w Teatrze im. Stefana Jaracza wynika, że twórcy biorą pod uwagę to, do jakiej publiczności będą kierować swoją wypowiedź artystyczną. Mam wrażenie, że nawet jak odczytujemy jakąś sztukę, która nie ma żadnych akcentów związanych z naszym miastem, to odczytujemy ją „na sposób łódzki”. Klimat miasta wpływa na pracę - to jest trudne do wytłumaczenia, ale odczuwalne.

Zdzisław Jaskuła odczuwa pewien niedosyt w zakresie podkreślania przez twórców „lokalności” łódzkich teatrów:

Mówię o tym dlatego, że łódzkie teatry zawsze były niejako obok miasta. Nie wiem, czy definiowały swoją miejską specyfikę, a także, co się z tym łączy, swojego widza. Tymczasem ta łódzka specyfika jest wyczuwalna. Kiedy przed laty zrobiłem w Teatrze Studyjnym spektakl „Varieté Tuwim”, to był on najlepiej odbierany właśnie w Łodzi. Pokazywaliśmy go też w innych miastach i nigdzie nie był odbierany tak dobrze, jak w naszym mieście.

\section{Lódzka publiczność}

Aktor i widz - bez spotkania tych dwojga teatr nie byłby możliwy. Dla Jurji Dawydowa publiczność jest „osobliwym elementem sztuki teatru”24, dla Margaret Dietrich jest ona wręcz, „̇̇yznym gruntem niezbędnym dla właściwego rozwoju flory"25.

Łódzka publiczność z końca XIX w. określana była jako dość trudna. Jerzy Urbankiewicz, za Bolesławem Gorczyńskim, opisuje ją w następujący sposób:

Publiczność łódzką ciągle niepokoi pytanie: czy naprawdę warto dziś pójść do teatru? Czy aby bardzo warto? Czy dają tam dziś dobry towar? Czy bardzo dobry? ${ }^{26}$ Wynikało to w dużej mierze ze struktury społecznej miasta, w którym dominowali robotnicy, nie mający ani wystarczających środków finansowych na zakup biletów, ani też wystarczająco dużo czasu na wizyty w teatrze ${ }^{27}$.

Jak prezentuje się współczesna łódzka publiczność? W 2003 r. ukazała się książka Emilii Zimnicy-Kuzioły pt. Światła na widownię. To pogłębiona socjologiczna analiza zbiorowości, jaką jest publiczność teatralna, przygotowana

${ }^{24}$ J. N. Dawydow, Psychologia społeczna a teatr, [w:] W kręgu socjologii teatru na świecie, wybór i oprac. T. Pyzik, E. Udalska, Wrocław 1987, s. 255.

${ }^{25}$ M. Dietrich, Aktor i publiczność, [w:] W kręgu socjologii teatru..., Wrocław 1987, s. 230.

${ }^{26}$ J. Urbankiewicz, Sezon $w$ Łodzi nie zaszkodzi, Łódź 1978, s. 8-9.

${ }^{27}$ Tamże, s. 14. 
na podstawie wieloetapowych badań zrealizowanych przez autorkę właśnie w Łodzi ${ }^{28}$. Zimnica-Kuzioła podzieliła widzów na następujące grupy: aspirant - widz, niezaznajomiony ze światem teatru, ale wykazujący pewne nim zainteresowanie; egotyk - widz oczekujący, by sztuka była odzwierciedleniem życia, szukający w niej potwierdzenia własnych przeświadczeń na temat rzeczywistości; ignorant - sztuka teatralna nie jest przedmiotem jego zainteresowań; widz statystyczny - zainteresowany fabułą i sposobem wystawienia sztuki; teatroman - zaprzyjaźniony z teatrem, znawca; literat - a może wręcz poeta, w teatrze poszukuje natchnienia, prawdy o życiu i sobie samym; krytyk - esteta, skupia się na warsztatowych aspektach sztuki teatru, nie interesuje się zbytnio jej odniesieniami do rzeczywistości ${ }^{29}$.

Powyższa charakterystyka nosi znamiona uniwersalności, można pytać, czy łódzki widz wyróżnia się w jakiś szczególny sposób?

Bronisław Wrocławski twierdzi, że nie:

Widz łódzki, ten który przychodzi do teatru z własnej woli, jest bardzo dobrym widzem. Nie różni się od innych. Potrzebuje porządnej sztuki... czyli takiej zrobionej w pewnym porządku. Mówiąc o porządku mam na myśli zasady... Przedstawienie powinno być czytelne, a bazą do jego powstania jest utwór dramatyczny.

Zdzisław Jaskuła zauważa, że łódzką publiczność trudno jest definiować tak jak kiedyś, przez pryzmat robotniczego charakteru miasta oraz jego wielokulturowości:

Kiedyś definiowaliśmy Łódź przez włókniarki, przemysł, tego molocha tekstylnego. Dzisiaj nie wiadomo, jaka jest Łódź, jaka jest jej tożsamość. Mówi się o wielokulturowej Łodzi, ale to już przeszłość.

Ewa Pilawska dostrzega jednak specyfikę łódzkiej publiczności:

Myślę, że mam wysoką świadomość miejsca, w którym tworzę teatr. Choć nie jestem łodzianką z urodzenia, żyję tu już wiele lat i wiem, co to znaczy, że korzeniami tego miasta są Bałuty i z dużą świadomością tych korzeni prowadzę Teatr Powszechny.

Wyjątkowość lokalnej publiczności docenia Agnieszka Więdłocha:

Mam wrażenie, że łódzki widz jest bardzo otwarty na sztukę. Jest mniej zmanierowany niż ten warszawski. Idąc do teatru liczy na jakieś przeżycia, nie tylko po to, by zobaczyć na scenie gwiazdy znane z telewizji. Oczywiście w tym nie ma nic złego. Łódzkie teatry również mają znanych aktorów, którzy przyciągają publiczność. W moim odczuciu jednak, to nie znane

${ }^{28}$ E. Zimnica-Kuzioła, Światta na widownię. Socjologiczne studium publiczności teatralnej, Łódź 2003.

${ }^{29}$ E. Zimnica-Kuzioła, Widz teatralny - typologia odbiorców sztuki scenicznej i ich dyskursów, „Folia Sociologica” 2001, nr 29, red. D. Walczak-Duraj. 
nazwiska są główną motywacją dla łódzkiego widza, by przyjść do teatru, lecz potrzeba kontaktu ze sztuką.

Tworząc, warto odwoływać się do tego, co w danym miejscu jest wyjątkowe, do opisywanej wcześniej specyfiki miasta. Marcin Brzozowski otwiera się na widzów poszukujących w teatrze nowatorstwa i deklaruje:

Moje działanie zmierza do poszerzenia oferty teatralnej w możliwie największym zakresie, przy czym kieruję uwagę na wydarzenia nowatorskie, niekomercyjne i posiadające kontekst społeczny. Nie jest to proste, ponieważ Teatr Szwalnia jest ciągle w fazie narodzin. Mam nadzieję, że ten proces się wkrótce zakończy i o ile przetrwamy, będziemy mogli żyć pełnią teatralnego życia.

\section{Główne problemy lódzkich scen}

Największym problemem twórców łódzkich teatrów są zbyt małe, w stosunku do potrzeb, fundusze. Finansowe problemy, o jakich wspominają indagowani, mają dwa oblicza: bezpośrednio dotyczące teatralnych budżetów oraz dotykające ich pośrednio poprzez skromne możliwości ekonomiczne mieszkańców miasta.

Łódź kojarzona jest w Polsce przede wszystkim z przemysłem tekstylnym dziś należałoby dodać - upadającym przemysłem tekstylnym. Nierozwiązanym problemem pozostaje rosnące bezrobocie. Badania potwierdzają tezę, że wzrasta liczba osób zmagających się z biedąa

Bronisław Wrocławski rozumie codzienne dylematy łodzian:

Sytuacja teatrów łączy się silnie z ogólną sytuacją miasta... a ta nie jest najlepsza. Nie wiem z czego to wynika, ot taki nasz los. Kiedy powstanie klasa średnia, ludzie będą w stanie zapewnić sobie nieco więcej niż podstawowe środki do życia, to wierzę, że z chęcią sięgną po dobrą literaturę, z chęcią wybiorą się do teatru. Teraz liczymy głównie na młodzież oraz na tę garstkę teatromanów - z kolegami żartobliwie ją nazywam sosjerką łódzką. A w tej łódzkiej sosjerce mieści się może ze 3 tysiące osób.

Podobny wydźwięk mają wypowiedzi pozostałych respondentów:

Agnieszka Więdłocha:

Zdaję sobie również sprawę z faktu, że Łódź jest trudnym miastem, borykającym się z wieloma problemami [...] Łódź jest też biednym miastem. Siłą rzeczy przekłada się to na funkcjonowanie tutejszych teatrów.

\section{Ewa Pilawska:}

Podstawowym problemem łódzkiego teatru, podobnie jak w innych częściach kraju, jest wysokie bezrobocie, wielka bieda miasta, i łączący się z nim brak poczucia bezpieczeństwa. Naturalnym

${ }^{30}$ Zob. W. Warzywoda-Kruszyńska, J. Grotowska-Leder, Wielkomiejska bieda $w$ okresie transformacji, Omega - Praksis, Łódź 1996 lub W. Warzywoda-Kruszyńska, J. Grotowska-Leder, J. Krzyszkowski, Lokalna polityka wobec biedy: bieda poza granicami wielkiego miasta, Łódź 2003. 
jest, że przenosi się to przede wszystkim na uczestnictwo w życiu kulturalnym. Kiedy „trudno związać koniec z końcem", to zrozumiałe, że nie myślimy o uczestniczeniu w wystawie, spektaklu czy seansie.

Zdzisław Jaskuła:

Przeciętny mieszkaniec Łodzi jest biedny, a równocześnie wytwarza się klasa średnia, która ma możliwość przeznaczenia większych kwot na kulturę. Mam również wrażenie, że taki powrót do teatru, który jest widoczny od 2-3 lat, wynika ze zmęczenia widza innymi formami rozrywki. Ludzie chcą odejść od komputera, od telewizora. Dzięki temu wszystkie teatry notują wzrost sprzedaży biletów.

Marcin Brzozowski podejmuje trudny temat organizacji pracy prowadzonego przez siebie teatru oraz niełatwych relacji z władzami:

Problemem są prawie zawsze pieniądze i sposób organizacji pracy. Myślę, że strasznie duże pieniądze są, z mojego punktu widzenia, marnotrawione w instytucjach kultury. Nie bez znaczenia jest tu chociażby działalność związków zawodowych artystów. Efektem jest przerost zatrudnienia. Na niepotrzebne etaty wydawane są ogromne pieniądze. Teatry, i to jest kolejny problem, są niestety podporządkowane i w dużym stopniu zależne od zmieniających się co kilka lat władz. W tak zwanej instytucji niezależnej, bierze się całkowitą odpowiedzialność za każdą wydaną złotówkę oraz decyzję programową. W przypadku działań nieracjonalnych lub zaniedbań, taka instytucja z dnia na dzień przestaje istnieć.

Zdaniem Bronisława Wrocławskiego, warto zwrócić uwagę na politykę repertuarową teatrów. Aby dać widzom ,szeroki wachlarz możliwości”, na afiszach przez długi czas utrzymuje się wiele tytułów. W efekcie, po premierze, dane przedstawienie pokazywane jest dwa-trzy razy w miesiącu. Zanim dojdzie do jego pełnego rozkwitu, a to zdaniem aktora następuje koło 20-tego przedstawienia, mija ponad pół roku. Wrocławski zastanawia się, czy jest to najlepsze rozwiązanie:

Może powinno być tak, że dane przedstawienie gra się 50-60 razy, a jak publiczność się nasyci, to jest ono zdejmowane $\mathrm{z}$ afisza, tak jak było to kiedyś czynione.

Problemem jest również brak alternatywnych form zatrudnienia dla aktorów w Łodzi. Chcąc podreperować domowy budżet, zmuszeni są oni do częstych wizyt w stolicy, gdzie odbywają się prawie wszystkie castingi. Wielu przenosi się do Warszawy na stałe, by nie tracić nadarzających się okazji zawodowych. Co to oznacza dla Łodzi? Jak zauważa Bronisław Wrocławski, konsekwencją takiego stanu rzeczy jest przedefiniowanie idei zespołowości. Trupa aktorska składa się $\mathrm{z}$ artystów dojeżdżających do teatru - co bez wątpienia nie ułatwia układania repertuaru (tak by pogodzić go ze wszystkimi zobowiązaniami aktorów).

\section{Mamy się czym pochwalić...}

Prośba o wskazanie osób/wydarzeń/miejsc, które najlepiej reprezentują Łódź na teatralnej mapie Polski, spotkała się z pewnym oporem wśród niektórych moich rozmówców (Bronisław Wrocławski, Ewa Pilawska). Bali się, że kogoś 
pominą, woleli więc zająć neutralne stanowisko w tej kwestii, co nie znaczy, że nie dostrzegają zalet łódzkich teatrów.

Agnieszka Więdłocha uważa, że Łódź najlepiej reprezentują: Bronisław Wrocławski, Mariusz Grzegorzek, Sambor Czarnota, Kamil Maćkowiak. Jej zdaniem, ogromny potencjał ma Marcin Łuczak. Zdzisław Jaskuła również wskazuje na Mariusza Grzegorzka oraz Bronisława Wrocławskiego. Jego zdaniem, warto również wyróżnić artystów odpowiedzialnych za plastyczną stronę teatru: Waldemara Zawodzińskiego oraz Ewę Kwiatkowską-Bloom.

Bronisław Wrocławski stwierdza, że mieszkańcy Łodzi niedostatecznie doceniają swoje miasto. Tymczasem on świadomie swoje życie zawodowe związał z Lodzią:

Jako rodowity łodzianin zawsze tu chciałem budować swoją karierę. Teraz nawet nie widzę innej możliwości. Przykro mi słyszeć, że młodzi ludzie uciekają z Łodzi, że gdzie indziej szukają swoich szans. Gdyby miasto stworzyło im odpowiednie warunki do rozwoju, pewnie by zostali. Pytanie jednak, jak to zrobić? Co zmienić? Znalezienie odpowiedzi wbrew pozorom nie jest łatwe. Sam nie wiem od czego zacząć.

\section{Również Marcin Brzozowski postanowił pozostać w Łodzi:}

Tuż po szkole, na krótko wyjechałem do Warszawy. Wróciłem jednak do Łodzi. Jak się okazało, było to najlepsze miejsce do rozpoczęcia działań artystycznych. Na rzecz pozostania w Łodzi przemawiały również względy ekonomiczne, fakt posiadania tu mieszkania. Miałem przygotowanych kilka spektakli, z którymi jeździłem po kraju - Łódź była świetną bazą wypadową do tych wojaży. Szkoła filmowa nieodpłatnie wynajmowała mi sale na próby. Nie chcąc uczestniczyć w castingach, potrzebowałem przestrzeni do niezależnej pracy. Łódź to umożliwiała. Poza tym, jestem łodzianinem, wychowałem się tutaj. Ja sobie nie wyobrażam, na dłuższą metę, życia w innym mieście. Na wsi tak, ale nie w innym mieście. Tu mi jest bardzo dobrze. A teraz z Łodzią wiąże mnie także Szwalnia.

Zdaniem Agnieszki Więdłochy, los miasta oraz możliwość rozwoju instytucji kulturalnych zależy także od jego mieszkańców:

Władze miasta mogą poprzeć działania mieszkańców - ale Ci muszą domagać się swoich praw. To w naszych rękach jest los miasta. To my mamy chodzić do teatru, uczestniczyć w różnych wydarzeniach kulturalnych, pokazać, że nam zależy na tym, by oferta kulturalna miasta rosła.

Zdzisław Jaskuła ceni poziom łódzkich teatrów kierujących swoją ofertę do najmłodszych widzów:

Najlepiej reprezentują nas teatry lalkowe. Także Teatr im. Stefana Jaracza jest zapraszany na różne festiwale i często przyjeżdża z nagrodami. Teatr Nowy dopiero zaczyna odbudowywać swoją markę, choć pomału zaczynają się pojawiać pierwsze zaproszenia. 


\section{Rzecz o finansowaniu kultury}

Od jakiegoś czasu w środowisku teatralnym toczy się dyskusja dotycząca udziału państwa w finansowaniu kultury ${ }^{31}$. Powstała nawet grupa protestująca przeciwko zmniejszaniu dotacji dla instytucji kultury. Łódzkie teatry, w zdecydowanej większości, funkcjonują w oparciu o dotacje państwowe (z Urzędu Miasta lub Urzędu Marszałkowskiego), wpływy z biletów i środki uzyskane od sponsorów oraz z dotacji unijnych. Ewa Pilawska zauważa, że coraz większą rolę w budowaniu budżetu teatrów odgrywa samodzielność, umiejętność pozyskiwania alternatywnych dla dotacji źródeł finansowania:

W naszym przypadku na przykład dotacja miejska nie pokrywa kosztów stałych utrzymania teatru, dlatego - jak wszystkie inne instytucje - staramy się pozyskiwać finanse z zewnątrz. I muszę powiedzieć, że szczęśliwie nam się to udaje. A nawet - na przestrzeni lat - widzę progres, bo udział procentowy wpływów własnych do dotacji z roku na rok wzrasta (w 2008 roku wyniósł on 50,13\%, w 2009 roku 69,31\%, a w 2010 roku już 70,41\%). Zabiegamy również o granty i środki unijne. $\mathrm{Z}$ tych ostatnich korzystaliśmy przy budowie Małej Sceny.

Zdzisław Jaskuła zauważa, że budżety łódzkich teatrów nie są równe:

Łódzkie teatry borykają się z problemami finansowymi. W niektórych przypadkach finansowe dylematy są większe. Trudno mówić o równych szansach na rozwój, kiedy Teatr Nowy ma dotację wynoszącą niecałe 5 milionów, a Teatr im. Stefana Jaracza dwukrotnie więcej. Różnica jest ogromna. Tam się inaczej zarabia.

Walka o przetrwanie Teatru Szwalnia to codzienność dla założyciela tej instytucji, Marcina Brzozowskiego:

Gramy spektakle, organizujemy wydarzenia artystyczne, realizujemy zadania publiczne współfinansowane ze środków publicznych. Ze względu na wysoki koszt utrzymania budynku, jesteśmy stale na granicy bankructwa. Niestety, system finansowania organizacji pozarządowych wyklucza dotację celową długoterminową na działalność teatru. Obecnie prowadzimy rozmowy w celu zmiany sposobu użytkowania lokalu, tak, aby móc w nim zarabiać na utrzymanie.

\section{Promocja teatru i edukacja teatralna}

Czy potrzeba jakiegoś szczególnego przygotowania do odbioru sztuki teatralnej? Zdaniem Agnieszki Więdłochy, nie jest to konieczne:

Nie trzeba mieć specjalnego przygotowania, by wiedzieć czy coś nam się podoba czy nie. Zaryzykowałabym tezę, że czasem wręcz jakiś akademicki dyskurs, poszukiwanie w niej ukrytych

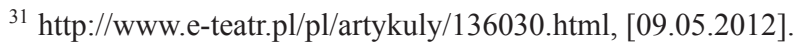


znaczeń i symboli, może nas zamknąć na zwykłe przeżywanie sztuk. Wielu ludzi rezygnuje z wizyt w teatrze, wychodząc z założenia, że się nie zna na sztuce. To błędne myślenie. Najważniejsze jest bowiem to, co się czuje, a nie to, co się wie po wyjściu z teatru. Zadaniem reżysera i aktorów jest obudzenie w widzach emocji, a nie sprawdzanie ich wiedzy.

Teatry, jej zdaniem, mają przede wszystkim uwrażliwiać ludzi, budzić w nich potrzebę obcowania ze sztuką. Wiele teatrów podejmuje dodatkowe wysiłki, aby osiągnąć ten cel. Teatr Nowy organizuje spotkania literackie (Mała literacka), wystawy. Teatr im. Stefana Jaracza, w ramach projektu Regionalne sceny, prezentuje swoje przedstawienia w innych miastach województwa, Teatr Szwalnia otwiera się na ludzi młodych i na ich działania, Teatr Powszechny z sukcesem, od lat buduje prestiżowy Festiwal Sztuk Przyjemnych i Nieprzyjemnych.

Zdzisław Jaskuła stwierdza:

Oczywiście samo zaproszenie widza na przedstawienie jest też działaniem edukacyjnym. Rzeczywistość pokazuje jednak, że to nie wystarcza. Z punktu widzenia dyrektora teatru, ważne jest, by wychować sobie widza, przygotować go do odbioru sztuki. Co nie znaczy, że należy do niego przemawiać jedynie archaicznym językiem, pokazywać tylko konwencjonalne oblicze teatru.

Marcin Brzozowski chce realizować konkretny program „wychowania do sztuki teatru":

Myśląc poważnie o edukacji teatralnej, należy jak najszybciej zejść ze sceny, by stwarzać przestrzeń spotkania i wspólnego tworzenia. Program edukacyjny Szwalni w dużej mierze bazuje na oddaniu teatru we władanie młodym ludziom, licealistom, studentom, absolwentom PWSFTviT.

Także Bronisław Wrocławski podkreśla, jak ważna jest edukacja teatralna dzieci i młodzieży:

To ważne, by uczyć dzieci od małego, że w teatrze dzieje się coś pięknego, coś tajemniczego. Jeśli na 10 osób w dwóch zostanie choćby cząstka tej teatralnej pasji - to już jest coś. I taka praca, by oswoić młodych z teatrem, jest w Łodzi podejmowana - chociażby w trakcie Łódzkich Spotkań Teatralnych. Sam również odwiedzam przedszkola, szkoły, starając się zarazić młodych miłością do teatru.

Ewa Pilawska widzi efekty swojej pracy „edukacyjnej”:

Uważam, że najważniejsza jest rozmowa, trzeba być otwartym na to, jaka widownia przychodzi do nas, a tym samym czego oczekuje od teatru. Znakomitym tego przykładem jest nasz Festiwal. Początkowo był to festiwal niekłopotliwych fars i komedii z gwiazdami w obsadzie. Przez kolejne lata, stopniowo, wprowadzałam „trudniejsze” spektakle, przygotowując widzów do kontaktu z bardziej wymagającymi intelektualnie propozycjami. Oczywiście po drodze widownia Festiwalu ulegała zmianie. Część widzów oczekujących jedynie lekkiej rozrywki odeszła, przyszli nowi. Ale część widzów towarzyszy nam od lat.

Niezwykle ważną rolę w promowaniu działań teatralnych odgrywają media. Bronisław Wrocławski podkreśla, że ceni sobie współpracę z Radiem Łódź czy Telewizją Łódzką: 
Osobiście nie mogę narzekać. Te media, z którymi ja współpracuję, robią, co mogą [...] Wiem jaka jest miara, że więcej nie da się zrobić. Trudno oczekiwać, by program informacyjny zawierał jedynie treści dotyczące kultury.

Słowa uznania nie oznaczają, że niepotrzebne są pewne zmiany. Świadczą o tym opinie pozostałych respondentów na temat łódzkiej krytyki teatralnej:

Ewa Pilawska:

Jeśli chodzi o łódzkie dziennikarstwo teatralne, to odnoszę wrażenie, że jego największą bolączką jest fakt, że brakuje nam dziennikarzy z odpowiednim wykształceniem i doświadczeniem. Często odnoszę wrażenie, że pewne błędy, jakie wkradają się w ich materiałach, nie wynikają z niechęci, lecz z braku przygotowania merytorycznego. Są oni - z jednej strony - zbyt ,zamknięci” lokalnie i przez to nie mają porównania z tym, co dzieje się w innych ośrodkach teatralnych. $Z$ drugiej strony, zaskakujące są częste rotacje. Poza kilkoma osobami, które są obecne w łódzkich mediach od lat, nie pojawia się nowe pokolenie, które proponowałoby nowe spojrzenie na życie teatralne miasta.

\section{Agnieszka Więdłocha:}

Mam wrażenie, że informacji o teatrze w prasie jest za mało. Prasa codzienna nie wystarcza. Nie ma debaty społecznej na temat tego, co się dzieje w teatrach. Jeżeli są informacje, to krótkie, szczątkowe. Nie chce mi się wierzyć w to, że ludzie nie chcieliby tego czytać.

\section{Zdzisław Jaskuła:}

Mankamentem łódzkiej krytyki teatralnej jest niekiedy brak kontekstu ogólnopolskiego. Poza tym, ciągle niewiele miejsca poświęca się wydarzeniom teatralnym. Często gazetowa recenzja to pół kartki maszynopisu. To za mało na rzetelną ocenę, z którą można byłoby polemizować. Ocena spektaklu nierzadko bazuje na preferencjach krytyka, jest kwestią jego gustu. Brakuje mi natomiast jasnych kryteriów oceny, takiego „kręgosłupa krytycznego”, wytyczającego linię oceny przedstawień. Poza tym, pisanie recenzji na podstawie jednorazowego obejrzenia spektaklu, zwłaszcza na premierze, jest dość ryzykowne. Kiedyś tak nie było. Recenzenci czasem przychodzili na próby, rozmawiali z twórcami, oglądali jakieś przedstawienie popremierowe. Teraz już się tego nie praktykuje.

\section{Na współpracę z mediami narzeka Marcin Brzozowski:}

Media były najbardziej aktywne, gdy zamykaliśmy naszą pierwszą siedzibę na Jaracza. Wtedy było o nas głośno. Pisano: „Zabrano teatrowi siedzibę!”. Wzmożone zainteresowanie trwało 2 tygodnie..., wtedy gdy wszystko się waliło. Natomiast nikogo nie interesuje nasza codzienna praca i walka. O tyle szkoda, że uwaga mediów bardzo pomaga w tworzeniu stałej widowni.

\section{Próba rekapitulacji}

Instytucje artystyczne wprowadzają sztukę w społeczny obieg, zapewniają trwałość przekazu artystycznego ${ }^{32}$. Wypadkową powyższych funkcji jest rów-

${ }^{32}$ M. Golka, Socjologia sztuki, Warszawa 2008, s. 43. 
nież edukowanie, a tym samym nakierowanie na rozwój kulturowy społeczeństwa. Łącząc instytucje kultury z kontekstem społecznym, w jakim przyszło im działać, należy zauważyć ich ogromny wpływ na promowanie miasta i regionu.

Próbę diagnozy stanu łódzkiej kultury podjęto w czasie Kongresu Kultury (Łódź, październik 2011 r.). Kilka dni obrad, spotkań twórców, teoretyków i praktyków z władzami miasta, miało przynieść nowe rozwiązania, poprawę istniejącego stanu rzeczy. Najważniejsza jednak była idea dialogu, wynikająca z potrzeby stworzenia pomostu, łączącego to, co ludzkie, z tym co urzędowe. Na ocenę jego skuteczności przyjdzie jeszcze pora. Nie zmienia to faktu, że artyści oraz zarządzający łódzkimi teatrami stale muszą podejmować starania o godne reprezentowanie miasta, o przyciąganie widzów i coraz lepszych artystów. Podsumowując rozmowę, moi respondenci skupiali się na swoich planach i marzeniach teatralnych:

\section{Bronisław Wrocławski:}

Muszę wrócić do tego, co powiedziałem na początku, do moich marzeń, by było 14 teatrów w Łodzi. W końcu to jest ponad siedemsettysięczne miasto. Są miejsca na świecie nasycone teatrami. Kolega mój, Mariusz Jakus, przyjechał parę dni temu z Kijowa z taką relacją: „Bronek! W Kijowie koniki sprzedają bilety na bieżące przedstawienia!!!”. Co takiego jest w Kijowie, że ludzie ustawiają się tam w długich kolejkach do teatru? Coś kryje się w mentalności ludzkiej, coś co rodzi potrzebę sztuki. My możemy tylko nad tym popracować. Dmuchać na te żarzące się węgle ludzkiego zapału i dbać o to, by ów zapał nie zgasł.

Zdzisław Jaskuła uważa, że poziom łódzkiego teatru jest przeciętny, ale próbuje znaleźć sposób na zmianę istniejącego status quo:

Jak to zmienić - odważniej zapraszać czołowych twórców. Potrzebny jest wspólny wysiłek, by o naszych przedstawieniach mówiono w kraju, miasto powinno zabiegać o to również. Powinny być odpowiednie środki na ten cel. W proces ten powinny się włączyć również media. Istotne jest również wzmocnienie promocyjne teatru, a także rzetelna krytyka teatralna.

Ewa Pilawska konkluduje swój wywiad następująco:

Myślę, że o to, jaki powinien być łódzki teatr należy zapytać widzów, bo to publiczność weryfikuje wszystkie nasze plany i podejmowane dążenia. My oczywiście będziemy rozwijać projekty Polskiego Centrum Komedii, tym bardziej że już wkrótce będziemy mieli do tego nową przestrzeń Małej Sceny. Natomiast jeśli pyta Pani bardziej globalnie o przyszłość łódzkiego teatru, to wierzę, że będzie się on rozwijał, że będzie się tu pojawiać coraz więcej ważnych nowych twórców i że będzie ważnym punktem na mapie teatralnej naszego kraju. I traktuję te słowa zarówno jako życzenia, jak i plany dla łódzkiego teatru, bo myślę, że o to właśnie powinniśmy zabiegać.

Marcin Brzozowski wysuwa konkretne postulaty i wskazuje na strategie adaptacyjne teatrów, starające się funkcjonować w ramach gospodarki wolnorynkowej: 
Powinno się uprościć procedury pozyskiwania i rozliczania się ze środków przeznaczonych na działalność organizacji pozarządowych. Wysokość środków powinna być uzależniona od jakości dotychczasowej działalności. Po drugie istotne jest racjonalne i odpowiedzialne wydatkowanie środków publicznych. Żadnego finansowania związków zawodowych artystów, festynów i Dód. Po trzecie więcej niezależności od polityków.

Wypowiedź najmłodszej uczestniczki mojego sondażu, Agnieszki Więdłochy, będzie dobrym epilogiem przeprowadzonych przeze mnie rozmów:

Łódzki teatr nie jest komercyjny i za to go szanuję. Jest rzetelny, szanuje widza, jest dla niego, nie dla pieniędzy. Może jestem idealistką, ale tak czuję. Czego nam brakuje? Wydaje mi się, że czasem takiej lekkości, większej chęci do zabawy, bo o trudnych tematach też można mówić w lekki sposób. Łódzkie teatry ciągle starają się udowodnić wszystkim, że są coś warte... niepotrzebnie. Wydaje mi się, że ich marka i jakość są rozpoznawalne w Polsce na tyle, by móc podjąć jakieś artystyczne ryzyko, bez obaw o utracenie widzów czy prestiżu.

Pozostaje nadzieja, że spełni się choć część z tych postulatów, a artyści chętnie będą rozmawiać o stanie łódzkiej kultury. Tylko bowiem dzięki dialogowi i wspólnemu wysiłkowi będziemy w stanie wprowadzić konstruktywne zmiany i łódzkie życie teatralne będzie jeszcze bogatsze, intensywniejsze, barwniejsze. 